\title{
Identification of cells exfoliated from the rat kidney in experimental nephrotoxicity
}

\author{
T. L. HARDY \\ Toxicology Unit, Medicinal Research Division, Beecham Research Laboratories, The Pinnacles, Harlow, Essex
}

The finding of increased exfoliation rates of renal cells after the ingestion of mild analgesic and other drugs has raised the question of the significance of a celluria in assessing the extent or severity of renal damage.

Certain cells in the urine may be readily recognized by their characteristic morphology, the question of their having originated from the renal parenchymal tissue itself being excluded. For example, squamous epithelial cells from the urinary tract, erythrocytes, polymorphonuclear leucocytes (provided that these are not degenerate), and aggregates such as casts and plaques fall into this category. However, the differentiation of, say, renal tubular cells, mononuclear leucocytes, and small transitional epithelial cells may often prove difficult and certainly time-consuming when large numbers of samples have to be examined, as in the present-day programmes for safety assessment of new drugs.

A simple counterstain to assist in the differentiation of cells from other amorphous debris, especially when examining the urine collected from laboratory animals, is often used when examining fresh preparations of cells in counting chambers. For example, Balazs, Hatch, Zawidzka, and Grice (1963) used a composite eosin/methyl blue/picric acid stain described by Behre and Muhlberg (1937) and methylene blue itself is often used; Lippman (1957) described several nonspecific stains. However, such general cytological stains do not unfortunately provide a conclusive means of identification of the unfixed cells nor do they necessarily indicate their origin, and examination of the fresh unstained sediment, perhaps by phase contrast microscopy, will often provide as much information.

Prescott and Brodie (1964) described a composite peroxidase stain which Prescott (1965) subsequently used in his study of tubular cell exfoliation after the administration of mild analgesics to human volunteers, and the use of this reagent has since been described by other workers (Davies and Kennedy, 1967; Davies, Kennedy, and Saluja, 1968). This stain is of value in inflammatory states as it gives a positive reaction with granulocytes. However, in the rat, all mononuclear cells, including transitional epithelial cells from the ureter and bladder and the renal tubule, give the same negative reaction.
During the course of a recent study of the detection of early renal tubular damage in rats (Hardy, 1968) it was felt that there was still a need for the positive identification of cells as having issued from the renal tubules. One system thought worthy of attention was the oxidative enzyme succinic dehydrogenase (SDH). The histochemically demonstrated distribution of SDH in the rat kidney is well documented (Rutenburg, Wolman, and Seligman, 1953; Wachstein, 1955), the proximal and distal convoluted tubules and both the ascending and descending limbs of Henle being relatively rich in the enzyme.

\section{Methods}

The method chosen for the demonstration of SDH in fresh frozen sections of rat kidney and urinary tract tissue was that of Lillie (1965), which is based on the method described by Nachlas, Tsou, de Souza, Cheng, and Seligman (1957) using nitro blue tetrazolium. It has been found to be sensitive and simple to use and can be applied to the "labelling" of cells for enumeration in the counting chamber or for the preparation of permanent smears.

REAGENTS: Nitro blue tetrazolium (NBT)

$0 \cdot 1 \mathrm{M}$. phosphate buffer at $\mathrm{pH} 7 \cdot 6$

$\left\{\begin{array}{c}44 \mathrm{ml} .0 \cdot 1 \mathrm{M} \text {. disodium hydrogen } \\ \text { phosphate } \\ 6 \mathrm{ml} .0 \cdot 1 \mathrm{M} \text {. potassium dihydrogen } \\ \text { phosphate }\end{array}\right\}$
$0 \cdot 1 \mathrm{M}$. sodium succinate
$0 \cdot 1$ per cent. $w . / \mathrm{v}$. aqueous Safranin " $\mathrm{O}$ "

For the detection of SDH-containing cells in the urine, the sample should be centrifuged as soon as possible after collection and the deposit washed several times with physiological saline. The cellular deposit is then re-suspended and incubated at $37^{\circ} \mathrm{C}$. for $30 \mathrm{~min}$. in an incubation mixture composed of equal volumes of the $0 \cdot 1 \mathrm{M}$. phosphate and succinate and containing 0.02 per cent. w./v. NBT. After incubation is complete, the sample is re-centrifuged and re-sus;ended in 10 per cent. w./v. formol saline. The SDH-positive cells, coloured purple with precipitated di-formazan, may then be enumerated in a suitable counting chamber and exfoliation rates calculated, as for example in the method of Houghton and Pears (1957). If permanent preparations are required, an aliquot of the stained cell deposit may be counterstained in 0.1 per cent. $w . / v$. aqueous Safranin " $O$ " to demonstrate the nuclei, then washed with water, mounted on albuminized slides, air dried, and mounted in DPX. 


\section{Results}

By the use of this method, the increased numbers of cells seen in the urine deposits of rats after the subcutaneous administration of sodium chromate, uranyl nitrate, and neomycin sulphate-all proven renal tubule toxins known to cause desquamation of cells-were shown to be predominantly SDHpositive. Examination of fresh frozen sections and tissue scrapings confirmed that Zones 1, 2, and 3 of the kidney (the cortex and outer medulla but not the papilla) were rich in the enzyme. On the other hand the transitional epithelium of the ureter, bladder, and renal pelvis was completely non-reactive. In sections incubated at the same time in the same incubation mixture, there was a trace reaction in the muscularis of the bladder and ureter. Under the conditions described above, circulating leucocytes and erythrocytes did not give the visible reaction for SDH seen in cells shed from the renal tubule.

\section{Discussion}

At the present time there seems to be no satisfactory explanation of the likely cause, or causes, of a mild celluria or of its relevance in assessing the extent or severity of renal damage. On the one hand there appear to be substances, such as caffeine and lactose, the diuretic frusemide, and urea, which have been cited as causing an increased excretion rate of cells but which have not been incriminated as frank nephrotoxins (Prescott, 1965; Gent, Taylor, and Brook, 1965; Prescott, 1966). At the other end of the scale there are the obvious nephrotoxins, such as the heavy metal ions (Sharratt and Frazer, 1963; Davies and Kennedy, 1967) and neomycin (Hardy, 1968), which undoubtedly cause desquamation of cells from the renal tubules. Clearly, if the oral administration of such apparently innocuous substances as urea and lactose gives rise to increased exfoliation rates of renal tubular epithelial cells, then this must cast some doubt on the relevance of a mild celluria by itself as an indicator of actual or impending renal damage.

Of the most commonly-used therapeutic agents, aspirin and the salicylates are now well recognized as causing exfoliation of cells from the kidney (Scott, Denman, and Dorling, 1963; Prescott, 1965, 1966; Scott, 1966), though whether they should be labelled as nephrotoxins or not is open to question from the conflicting results of studies in animals. The defoliative action of aspirin on the gastric mucosal epithelium has also been demonstrated (Croft, 1963; Scott, 1966) and one wonders if perhaps the excessive numbers of cells seen is a result of a temporary potentiation in cell turnover rate, the urine and gastric juice being convenient media in which we can measure this. On the other hand, in the case of the kidney, it has been suggested that an alteration in the rate of renal flow may be the causative factor. If one accepts the possibility that some agents could cause shedding of epithelial cells in general, then cells appearing in the urine might come from any part of the urinary tract, apart from the nephron. The correct identification of the site of origin of the cells then becomes more important.

In addition to the usefulness of the demonstration of SDH in cells as a positive indication that cells are of renal origin, it was noted that the proportion of SDH-positive cells present varied with time. Thus, the cells exfoliated shortly after administration of a single high subcutaneous dose of neomycin sulphate to rats were predominantly enzyme-positive, whereas as time progressed there was a higher proportion of negative cells. This finding is compatible with the pattern of diminishing tissue enzyme found in the nephropathies, as reported for instance by Brain and Kay (1927), Breedis, Flory, and Furth (1943), Wachstein and Meisel (1954), and Spink and Landeryou (1960). Thus it is suggested that attention to the ratio of reactive to non-reactive cells appearing in the urine may also give some measure of the particular stage of development or severity of lesions of the renal tubule. Furthermore, by paying attention to other enzymes, it may be possible, perhaps by a differential analysis of several systems, to type cells as having issued from a particular segment of the nephron.

\section{Summary}

It is suggested that a histochemical approach to the labelling of cells found in the urine is of value in the positive identification of cells exfoliated from the renal tubule in experimental nephropathies. A method is described for the demonstration of succinic dehydrogenase in unfixed tubule epithelial cells so that these may be enumerated in a cytometer. Since the urinary tract epithelium of the rat is nonreactive, the finding of enzyme-rich cells in the urine after administration of nephrotoxins identifies these as having issued from the nephron. Furthermore, by calculating the ratio of reactive to non-reactive cells, it may be possible to predict the particular stage of development or severity of a kidney lesion and by a differential enzyme histochemical analysis to determine the site from which exfoliation has taken place. This approach is currently being applied to the screening of anti-inflammatory and analgesic drugs for nephrotoxicity.

The author wishes to thank Dr. S. J. Surtees, M.B., Ch.B., M.R.C.P., M.C.Path., D.T.M. and H., and Mr. D. M. Brown, B.Sc., F.P.S., F.I.Biol., for their advice and encouragement, and the Management of Beecham Research Laboratories for permission to publish the work. 


\section{References}

Balazs, T., Hatch, A., Zawidzka, Z., AND Grice, H. C. (1963) Toxic. appl. Pharmacol., 5, 661 (Renal tests in toxicity studies on rats).

Behre, J. A., AND MuHLberG, W. (1937) J. Lab. clin. Med., 22, 853 (A stain for urinary casts).

BraIN, R. T., AND KAY, H. D. (1927) Biochem. J., 21, 1104 (Kidney phosphatase. II. The enzyme in disease).

Breedis, C., Flory, C. M., AND FURTH, J. (1943) Arch. Path., 36, 402 (Alkaline phosphatase level in urine in relation to renal injury).

Croft, D. N. (1963) Brit. med. J., 2, 897 (Aspirin and the exfoliation of gastric epithelial cells).

AND Wood, P. H. N. (1967) Ibid., 1, 137 (Gastric mucosa and susceptibility to occult gastrointestinal bleeding caused by aspirin).

Davies, D. J., AND Kennedy, A. (1967) Toxic. appl. Pharmacol., 10, 62 (Course of the renal excretion of cells after necrosis of the proximal convoluted tubule by mercuric chloride).

- - _ and Saluja, P. G. (1968) Ann. rheum. Dis., 27, 130 (Significance of the urinary excretion of cells after experimental medullary necrosis).

Gent, A. E., TAYLOR, J. F. N., AND Brook, C. G. D. (1968) Brit. med. J., 4, 294 (Effect of frusemide, lactose, and urea on urinary cell loss).

HARDY, T. L. (1968) Thesis: The early detection of renal tubular damage in rats. Institute of Biology.

Houghton, B. J., and Pears, M. A. (1957) Brit. med. J., 1, 622 (Cell excretion in normal urine).

LILlIE, R. D. (1965) "Histopathologic Technic and Practical Histochemistry", 3rd ed. McGraw-Hill, New York.

Lippman, R. W. (1957) "Urine and the Urinary Sediment", 2nd ed. Thomas, Springfield, Ill.

Nachlas, M. M., Tsou, K. C., de Souza, E., Cheng, C. S., and Seligman, A. M. (1957) J. Histochem. Cytochem. 5,420 (Cytochemical demonstration of succinic dehydrogenase by the use of a new p-nitrophenyl substituted ditetrazole).

PrescotT, L. F. (1965) Lancet, 2, 91 (Effects of acetylsalicylic acid, phenacetin, paracetamol, and caffeine on renal tubular epithelium).

- (1966) J. Pharm. Pharmacol., 18, 331 (The nephrotoxicity of analgesics). AND BRODIE, D. E. (1964) Lancet, 2, 940 (A simple differential stain for urinary sediment).

Rutenburg, A. M., Wolman, M., and Seligman, A. M. (1953) J. Histochem. Cytochem., 1, 66 (Comparative distribution of succinic dehydrogenase in six mammals and modification in the histochemical technic).

ScotT, J. T. (1966) Amer. Heart J., 71, 715 (Phenacetin, aspirin, and kidney damage).

- Denman, A. M., AND Dorling, J. (1963) Lancet, 1, 344 (Renal irritation caused by salicylates).

Sharratt, M., AND Frazer, A. C. (1963) Toxic. appl. Pharmacol., 5, 36 (The sensitivity of function tests in detecting renal damage in the rat).

SPINK, W. W., AND LANDERYOU, M. J. (1960) J. clin. Invest., 39, 302 (Diminution in renal alkaline phosphatase in endotoxin shock).

WaChSTEIN, M. (1955) J. Histochem. Cytochem., 3, 246 (Histochemical staining reactions of the normally functioning and abnormal kidney).

- AND Meisel, E. (1954) Amer. J. Path., 30, 147 (Influence of experimental renal damage on histochemically demonstrable succinic dehydrogenase activity in the rat).

\section{RÉSUMÉ}

\section{L'identification des cellules exfoliées du rein du rat pendant} la néphrotoxicité expérimentale

Il est suggéré que la méthode histochimique pour marquer les cellules trouvées dans l'urine est de valeur pendant l'identification positive des cellules exfoliées des tubules rénales pendant les néphropathies expérimentales. Une méthode est décrite pour démontrer la déhydrogénase succinique dans les cellules épithéliales nonfixées des tubules de façon qu'on puisse les énumérer dans un cytomètre. Comme l'épithélium des voies urinaires du rat est non-réactif, le fait de trouver des cellules riches en enzymes dans l'urine après l'administration de néphrotoxines identifie celles-ci comme étant issues du néphron. De plus en calculant la proportion des cellules réactives aux cellules non-réactives, il serait, peut-être, possible de prédire l'état particulier de l'évolution ou la gravité de la lésion rénale et par une analyse histo-chimique différentielle d'enzymes de déterminer l'endroit où l'exfoliation à eu lieu. Cette façon de procéder est appliquée couramment pour vérifier la néphrotoxicité des médicaments analgésiques et anti-inflammatoires.

\section{SUMARIO}

Identificación de celulas exfoliadas de riñón de rata en nefrotoxicidad experimental

Se sugiere que la técnica histoquímica para la marcación de células halladas en la orina es valiosa en la identificación positiva de células exfoliadas de los túbulos renales en nefropatías experimentales. Se describe un método para la demostración de dehidrogenasa succínica en células epiteliales tubulares no fijadas, de modo que estas puedan ser enumeradas en un citómetro. Dado que el epitelio del tracto urinario de la rata no es reactivo, la presencia en la orina, de células ricas en enzimas después de la administración de nefrotoxinas identifica a estas células como procedentes del nefrón. Más aún, calculando la proporción entre las células reactivas y las no reactivas, sería posible predecir determinada etapa del desarrollo o severidad de una lesión renal y, mediante un análisis histoquímico diferencial de enzimas, determinar el lugar donde se ha producido la exfoliación. Esta técnica se aplica actualmente el estudio de las drogas antiinflamatorias y analgésicas para determinar su nefrotoxicidad. 